Review

\title{
Effects of rehabilitation for pain relief in patients with rheumatoid arthritis: a systematic review
}

\author{
Younguu Park, MS, OT ${ }^{1)}$, Moonyoung Chang, PhD, $\left.\mathrm{OT}^{2}\right)^{*}$ \\ 1) Department of Rehabilitation Science, Graduate School of Inje University, Republic of Korea \\ 2) Department of Occupational Therapy, College of Biomedical Science and Engineering, Inje \\ University: 197 Inje-ro, Gimhae-si, Gyeongsangnam-do 621-749, Republic of Korea
}

\begin{abstract}
Purpose] The purpose of this study was to find evidence for the effectiveness of rehabilitation for pain relief in patients with rheumatoid arthritis. [Subjects and Methods] A systematic review was conducted of MEDLINE, The Cochrane Central Register of Controlled Trials (CENTRAL), and OVID, for studies published from July 2005 to July 2015. We extracted data regarding patients, intervention, comparison, and outcomes, and assessed the methodological quality of the data. [Results] Nine randomized controlled trials comparing the effects of pain relief in patients with rheumatoid arthritis were found. [Conclusion] Physical therapy and occupational therapy can reduce pain in rheumatoid arthritis.

Key words: Pain, Rehabilitation, Rheumatoid arthritis
\end{abstract}

(This article was submitted Aug. 28, 2015, and was accepted Oct. 14, 2015)

\section{INTRODUCTION}

Rheumatoid arthritis (RA) is a leading cause of disability in adults in the U.S. ${ }^{1)}$. RA is a systemic, inflammatory condition causing pain, joint destruction and disability ${ }^{2}$. Pain is a common symptom in patients with rheumatoid arthritis and it is hard for them to cope with $\mathrm{it}^{3}{ }^{3}$. There are some non-pharmacological treatments ${ }^{4-7)}$ in rheumatologic care and noticeable advances over the past decade are changing the clinical course of $\mathrm{RA}^{8}$. Physical therapists and occupational therapists are multi-skilled professionals who treat patients with RA, and perform the role of case managers ${ }^{\text {) }}$.

A few studies suggest some evidence in which findings can benefit both therapists and clients in rheumatology care. However until now, no study has reviewed the effectiveness of pain intervention in patients with RA. Therefore, this is the first systematic review about pain relief for patient with RA. The aim of this study was to seek evidence for the effectiveness of rehabilitation for pain relief in patients with RA, and to suggest the guidelines of roles for physical therapists and occupational therapists.

\section{SUBJECTS AND METHODS}

For this study, we searched electronic databases using a strategy Mesh-term and free-text term. Then we performed a search of MEDLINE, The Cochrane Central Register of Controlled Trials (CENTRAL), and OVID, for studies published from July 2005 to July 2015, using the keywords: occupational therapy (OT), pain, physical therapy (PT), and rheumatoid arthritis. Studies identified were evaluated based on following the inclusion criteria: (1) subjects had RA, (2) study design: randomized controlled trials (RCTs), (3) had outcomes of pain relief, and (4) full text was available. Exclusion criteria were: (1) study was not an experimental study, (2) subjects had diseases other than RA, (3) study was about the development of evaluation tools, or (4) study design was review. Hand searching of journals and reference lists of relevant articles was also conducted without regard to languages.

\footnotetext{
*Corresponding author. Moonyoung Chang (E-mail: myot@inje.ac.kr)

(C)2016 The Society of Physical Therapy Science. Published by IPEC Inc.

This is an open-access article distributed under the terms of the Creative Commons Attribution Non-Commercial No Derivatives (by-nc-nd) License $<$ http://creativecommons.org/licenses/by-nc-nd/3.0/>.
} 
Two reviewers independently evaluated the titles and abstracts for selecting articles to be included or excluded from our study. Then, we read the full text of the studies in detail. Multiple studies were considered as one trial if they described a single trial. The methodological quality of the trials was also independently assessed using the Physiotherapy EvidenceBased Database (PEDro) scale ${ }^{10,11}$, a 10-point scale that has 11 items for the assessment of internal validity and statistical information in RCTs. Trials with a PEDro score greater than 5 are considered to be of moderate to high quality ${ }^{12)}$. A total score was determined through discussion, if there were disagreements between the two reviewers. Intervention outcomes were reported using the patient, intervention, comparison and outcome (PICO) method.

\section{RESULTS}

A total of 613 potentially relevant articles were identified based on the initial search, but 604 of them did not meet the inclusion criteria. Therefore, 9 studies ${ }^{13-21)}$ were identified for this analysis (Fig. 1). All the studies were RCTs and clinical trials. Four articles had a score $<6$ on the PEDro scale while the others had a score $\geq 6$ (Table 1).

Table 1 presents the summary of characteristics of the included studies according to the PICO method. There was a greater proportion of women than men in 8 of the studies. The kinds of OT and PT interventions used were various: exercise, cognitive behavioral therapy, education, or particular splint. In comparison, a control group was given: usual rheumatology care and conventional program, information about diagnosis or no intervention. For two studies, intervention was conducted by physical therapists and occupational therapists. Various assessment tools were used for assessing the outcomes, according to the purpose of the respective study. With the exception of two studies, there was significant improvement in the experimental group ${ }^{16,18)}$. PT including various exercises, education and assistive devices and OT including cognitive behavioral therapy, education, management and splints were effective methods for pain relief in patients with RA.

\section{DISCUSSION}

This study compared the effects of rehabilitation and rheumatology care for pain relief in patients with RA. The results indicated that PT and OT interventions are effective for pain relief in people with RA. In this review, most studies indicate that OT and PT interventions are more benefits than usual rheumatology care. These results are consistent with those of previous systematic reviews ${ }^{22,23}$. Many intervention methods and assessment tool were used in this study. Categorization of RA intervention and assessment in this study is similar to the four categorizations noted by de Almeida ${ }^{24)}$ : patient guidance and education, joint protection and energy conservation, modifying activities and environments, and assistive technologies. In a remarkable intervention, one study was carried out to determine whether comprehensive intervention promotes function in employed people ${ }^{17)}$. There is limited provision of vocational rehabilitation (VR) in the rheumatology area. It is suggested that VR is effective in increasing both knowledge and confidence in rheumatology ${ }^{25}$, so therapists try to involve and study this area. Another intervention, the therapy glove, decreases pain, stiffness, and swelling ${ }^{26)}$. It is an effective method in rehabilitation in RA. However, we exclude that intervention in our study, because it was composed of a case study and published before 2000 .

Currently, people with arthritis are diagnosed early and treated aggressively, so joint deformities and activity limitations are less common ${ }^{27)}$. Therefore, therapists will need to focus on preventive as well as compensatory strategies for public health ${ }^{8)}$

Limitations of this systematic review are that we did not conduct a meta-analysis. Nevertheless, this is the first study that systematically reviewed PT and OT interventions for pain relief in patients with RA. Systematic reviews an important study design for informing practice and, can provide suggestions for OT and PT researchers who define future research agendas, and can assist administrators and decision-makers who develop evidence based policies and guidelines ${ }^{28)}$. An important finding in our study, PT and OT intervention have some strong evidence of improvement for population with RA. We recommend that in the future, studies involving various and better intervention methods for patients with RA should be conducted.

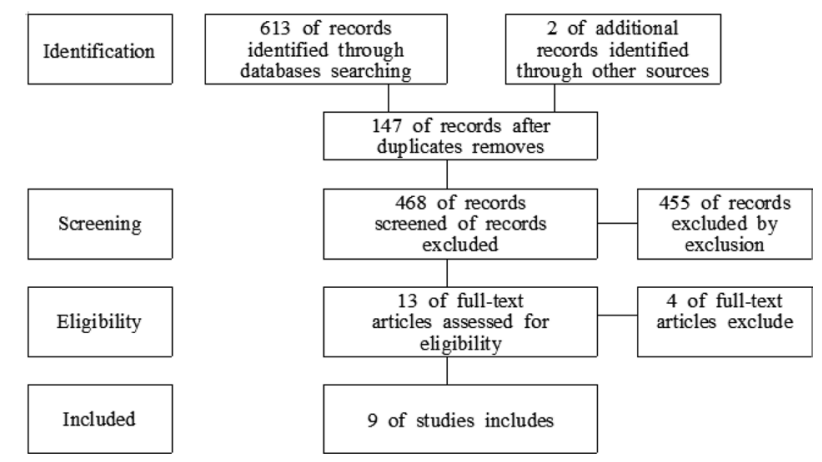

Fig. 1. Diagram on process about searching process 
Table 1. Summary of characteristics of included studies

\begin{tabular}{|c|c|c|c|c|c|c|}
\hline \multirow{2}{*}{ Evidence } & \multirow{2}{*}{$\begin{array}{l}\text { PEDro } \\
\text { score }\end{array}$} & \multirow{2}{*}{$\begin{array}{l}\text { Patient } \\
(\mathrm{IG} / \mathrm{CG})\end{array}$} & \multirow{2}{*}{ Intervention } & \multirow{2}{*}{ Comparison } & \multicolumn{2}{|l|}{ Outcome } \\
\hline & & & & & Assessment & Result \\
\hline $\begin{array}{l}\text { Rahnama } \\
\text { et al., 2015 }\end{array}$ & 5 & $\begin{array}{l}\mathrm{RA} \\
\mathrm{N}=48 \\
\text { Age }=58.6 \pm 7.8 \\
\mathrm{~F}: \mathrm{M}=\text { all M } \\
\mathrm{DD}=\text { no men- } \\
\text { tion }\end{array}$ & $\begin{array}{l}\text { aerobic exercise and } \\
\text { strengthening exercise } \\
30 \text { to } 45 \text { min. } 3 \text { days per wk. for } \\
8 \text { wks. }\end{array}$ & no intervention & $\begin{array}{l}\text { VAS (pain) } \\
\text { WOMAC (functional } \\
\text { ability) }\end{array}$ & $\begin{array}{l}\text { Pain relief and } \\
\text { functional abil- } \\
\text { ity improved in } \\
\text { exercise group. }\end{array}$ \\
\hline $\begin{array}{l}\text { Jahanbin } \\
\text { et al., 2014 }\end{array}$ & 6 & $\begin{array}{l}\text { RA } \\
65(32 / 32) \\
48.6 / 48.8 \mathrm{y} \\
\text { all } \mathrm{F} \\
\text { no mention }\end{array}$ & $\begin{array}{l}\text { conditioning, isotonic, isometric } \\
\text { and aerobic exercise } \\
45 \text { min. } 2 \text { times per wk. for } 8 \\
\text { wks. }\end{array}$ & received a booklet & $\begin{array}{l}\text { VAS (pain) } \\
\text { AIMS-2 (health status) }\end{array}$ & $\begin{array}{l}\text { Pain relief and } \\
\text { health status } \\
\text { improved in } \\
\text { exercise group. }\end{array}$ \\
\hline $\begin{array}{l}\text { Hewlett } \\
\text { et al., 2011 }\end{array}$ & 5 & $\begin{array}{l}\text { RA } \\
127(62 / 62) \\
59.2 \mathrm{y} \\
44: 18 / 49: 13 \\
14.6 / 14.2 \mathrm{y}\end{array}$ & $\begin{array}{l}\text { cognitive behavioral therapy } \\
\text { (CBT) group: } \\
\text { fatigue self-management } \\
6 \times 2 \text { h sessions for } 6 \text { wks. } \\
\text { Consolidation: } 1 \text { h sessions for } \\
14 \text { wks. }\end{array}$ & $\begin{array}{l}\text { fatigue self-man- } \\
\text { agement: } \\
1 \text { h sessions }\end{array}$ & $\begin{array}{l}\text { MAF (fatigue impact) } \\
\text { VAS (pain) }\end{array}$ & $\begin{array}{l}\text { Fatigue and } \\
\text { pain relief im- } \\
\text { proved in CBT } \\
\text { group. }\end{array}$ \\
\hline $\begin{array}{l}\text { Breedland } \\
\text { et al., 2011 }\end{array}$ & 5 & $\begin{array}{l}\text { RA } \\
34(19 / 15) \\
45.0 / 51.8 \mathrm{y} \\
12: 7 / 12: 3 \\
9.7 / 5.9 \mathrm{y}\end{array}$ & $\begin{array}{l}\text { group based exercise and } \\
\text { educational program } \\
60 \mathrm{~min} . \text { for } 8 \mathrm{wks} .\end{array}$ & no intervention & $\begin{array}{l}\text { AIMS-2 (health status) } \\
\text { ASES (pain) }\end{array}$ & $\begin{array}{l}\text { No significant } \\
\text { differences be- } \\
\text { tween groups. }\end{array}$ \\
\hline $\begin{array}{l}\text { Macedo } \\
\text { et al., 2009 }\end{array}$ & 7 & $\begin{array}{l}\text { employed RA } \\
32(16 / 16) \\
48.6 / 52.6 y \\
15: 1 / 15 ; 1 \\
11.6 / 8.4 y\end{array}$ & $\begin{array}{l}\text { comprehensive occupational } \\
\text { therapy (COT) group: } \\
\text { education, compliance and man- } \\
\text { agement } 30 \text { min. }-2 \mathrm{~h} \text { of each } \\
6-8 \text { session for } 6 \text { mon. }\end{array}$ & $\begin{array}{l}\text { usual care group: } \\
\text { medical manage- } \\
\text { ment and rheuma- } \\
\text { tology clinic visit }\end{array}$ & $\begin{array}{l}\text { COPM (function) } \\
\text { RA WIS (work produc- } \\
\text { tivity) } \\
\text { DAS } 28 \text { (disease activity) } \\
\text { VAS (pain) }\end{array}$ & $\begin{array}{l}\text { Function, work } \\
\text { productivity, } \\
\text { disease pain } \\
\text { relief improved } \\
\text { in COT group. }\end{array}$ \\
\hline $\begin{array}{l}\text { Adams } \\
\text { et al., 2008 }\end{array}$ & 8 & $\begin{array}{l}\text { RA } \\
112(56 / 60) \\
59.6 / 55.2 y \\
42: 14 / 42: 18 \\
8.6 / 12.4 \text { mon. }\end{array}$ & $\begin{array}{l}\text { static resting splints group: } \\
\text { splints+ standardized occu- } \\
\text { pational therapy for } 12 \mathrm{mon} \text {. } \\
\text { (nightwear) }\end{array}$ & $\begin{array}{l}\text { standardized OT } \\
\text { group: } \\
\text { JP education, } \\
\text { hand exercises }\end{array}$ & $\begin{array}{l}\text { hand deviation (defor- } \\
\text { mity) } \\
\text { MHQ (hand function) } \\
\text { VAS (pain) } \\
\text { grip strength }\end{array}$ & $\begin{array}{l}\text { No significant } \\
\text { differences be- } \\
\text { tween groups. }\end{array}$ \\
\hline $\begin{array}{l}\text { Hammond } \\
\text { et al., 2008 }\end{array}$ & 6 & $\begin{array}{l}\text { RA } \\
167(86 / 81) \\
55.6 / 55.3 y \\
57: 29 / 51: 30 \\
7.2 / 7.6 y\end{array}$ & $\begin{array}{l}\text { modular behavioral (MB) group: } \\
2.5 \mathrm{~h} \text { meeting, } 4 \text { sessions per wk. } \\
2 \mathrm{~h} \text { review, 1session } \\
\text { Module 1: behavioral JP pro- } \\
\text { gram } \\
\text { Module 2: initial discussion for } \\
18 \text { mon. }\end{array}$ & $\begin{array}{l}\text { standard educa- } \\
\text { tion program } \\
\text { group: } \\
2 \text { h meeting, } 5 \\
\text { session per wk. } \\
\text { (information, ex- } \\
\text { ercise, JP, healthy } \\
\text { diet) }\end{array}$ & $\begin{array}{l}\text { RASE (psychological } \\
\text { status) } \\
\text { VAS (pain) } \\
\text { HAQ (functional status) }\end{array}$ & $\begin{array}{l}\text { Psychological } \\
\text { status, pain } \\
\text { relief and func- } \\
\text { tional status } \\
\text { improved in } \\
\text { MB group. }\end{array}$ \\
\hline $\begin{array}{l}\text { Veehof } \\
\text { et al., 2008 } 20 \text { ) }\end{array}$ & 7 & $\begin{array}{l}\text { RA } \\
53(17 / 16) \\
66.3 / 55.1 \mathrm{y} \\
71: 29 / 69: 31(\%) \\
8.2 / 5.0 \mathrm{y}\end{array}$ & $\begin{array}{l}\text { prefabricated wrist working } \\
\text { splint (splinting) group: } \\
4 \text { wks. }\end{array}$ & $\begin{array}{l}\text { usual care group } \\
4 \text { wks. }\end{array}$ & $\begin{array}{l}\text { VAS, DASH (pain) } \\
\text { grip strength } \\
\text { DASH, SODA-S (func- } \\
\text { tional ability) }\end{array}$ & $\begin{array}{l}\text { Pain relief, grip } \\
\text { strength and } \\
\text { functional abil- } \\
\text { ity improved in } \\
\text { splinting group. }\end{array}$ \\
\hline $\begin{array}{l}\text { Li et al., } \\
2006^{21)}\end{array}$ & 4 & $\begin{array}{l}\text { RA } \\
111(63 / 48) \\
54.2 / 56.8 \mathrm{y} \\
55: 8 / 38: 10 \\
10.6 / 13.2 \mathrm{y}\end{array}$ & $\begin{array}{l}\text { primary therapist model (PTM) } \\
\text { group: } \\
\text { education } \\
\text { splints/ foot orthosis } \\
\text { psychosocial support } \\
\text { for } 6 \text { wks. }\end{array}$ & $\begin{array}{l}\text { traditional treat- } \\
\text { ment model } \\
\text { (TTM) group: } \\
\text { assistive devices } \\
\text { advice for modal- } \\
\text { ity aids }\end{array}$ & $\begin{array}{l}\text { HAQ (physical function) } \\
\text { VAS (pain) }\end{array}$ & $\begin{array}{l}\text { Physical func- } \\
\text { tion and pain } \\
\text { relief improved } \\
\text { in PTM group. }\end{array}$ \\
\hline
\end{tabular}

AIMS-2: Arthritis Impact Measurement Scale-2. ASES: Arthritis Self-Efficacy Scale. CG: Control Group. COPM: Canadian Occupational Performance Measure. DAS 28: Clinical evaluation consisted of disease activity score. DASH: Disabilities of the Arm Shoulder Hand questionnaire. DD: Disease Duration. F: females. HAQ: Health Assessment Questionnaire. IG: Intervention Group. JP: Joint Protection. M: Males. MAF: Multi-Dimensional Assessment of Fatigue Scale. MHQ: Michigan Hand Outcomes Questionnaire. N: Number of subjects. RA: Rheumatoid Arthritis. RA WIS: RA Work Instability Scale. RASE: RA self-efficacy. SODA-S: Sequential Occupational Dexterity Assessment short version. VAS: Visual Analog Scales. WOMAC: Western Ontario and McMaster Osteoarthritis Index 


\section{REFERENCES}

1) McNeil J, Binette J, Centers for Disease Control and Prevention (CDC): Prevalence of disabilities and associated health conditions among adults_-United States, 1999. MMWR Morb Mortal Wkly Rep, 2001, 50: 120-125. [Medline]

2) Scott DL, Steer S: The course of established rheumatoid arthritis. Best Pract Res Clin Rheumatol, 2007, $21: 943-967$. [Medline] [CrossRef]

3) Suurmeijer TP, Waltz M, Moum T, et al.: Quality of life profiles in the first years of rheumatoid arthritis: results from the EURIDISS longitudinal study. Arthritis Rheum, 2001, 45: 111-121. [Medline] [CrossRef]

4) Peungsuwan P, Sermcheep P, Harnmontree P, et al.: The effectiveness of thai exercise with traditional massage on the pain, walking ability and QOL of older people with knee osteoarthritis: a randomized controlled trial in the community. J Phys Ther Sci, 2014, 26: 139-144. [Medline] [CrossRef]

5) Lim KO, Lee DY, Shin WS: The effects of a warm whirlpool bath on pain and stiffness of patients with chronic stroke induced knee osteoarthritis. J Phys Ther Sci, 2013, 25: 873-875. [Medline] [CrossRef]

6) Nakata K, Kougo M, Huo M, et al.: The immediate effect of neuromuscular joint facilitation (NJF) treatment for knee osteoarthritis. J Phys Ther Sci, 2012, 24: 69-71. [CrossRef]

7) Aoki O, Tsumura N, Kimura A, et al.: Home stretching exercise is effective for improving knee range of motion and gait in patients with knee osteoarthritis. J Phys Ther Sci, 2009, 21: 113-119. [CrossRef]

8) Mallinson T, Fischer H, Rogers JC, et al.: Human occupation for public health promotion: new directions for occupational therapy practice with persons with arthritis. Am J Occup Ther, 2009, 63: 220-226. [Medline] [CrossRef]

9) Hurst K: Multi-skilled health carers: nature, purpose and implications. Health Manpow Manage, 1997, $23: 197-211$. [Medline] [CrossRef]

10) Maher CG, Sherrington C, Herbert RD, et al.: Reliability of the PEDro scale for rating quality of randomized controlled trials. Phys Ther, 2003, 83: 713-721. [Medline]

11) Macedo LG, Elkins MR, Maher CG, et al.: There was evidence of convergent and construct validity of Physiotherapy Evidence Database quality scale for physiotherapy trials. J Clin Epidemiol, 2010, 63: 920-925. [Medline] [CrossRef]

12) Moseley AM, Herbert RD, Sherrington C, et al.: Evidence for physiotherapy practice: a survey of the Physiotherapy Evidence Database (PEDro). Aust J Physiother, 2002, 48: 43-49. [Medline] [CrossRef]

13) Rahnama N, Mazloum V: Effects of strengthening and aerobic exercises on pain severity and function in patients with knee rheumatoid arthritis. Int J Prev Med, 2012, 3: 493-498. [Medline]

14) Jahanbin I, Hoseini Moghadam M, Nazarinia MA, et al.: The effect of conditioning exercise on the health status and pain in patients with rheumatoid arthritis: a randomized controlled clinical trial. Int J Community Based Nurs Midwifery, 2014, 2: 169-176. [Medline]

15) Hewlett S, Ambler N, Almeida C, et al.: Self-management of fatigue in rheumatoid arthritis: a randomised controlled trial of group cognitive-behavioural therapy. Ann Rheum Dis, 2011, 70: 1060-1067. [Medline] [CrossRef]

16) Breedland I, van Scheppingen C, Leijsma M, et al.: Effects of a group-based exercise and educational program on physical performance and disease self-management in rheumatoid arthritis: a randomized controlled study. Phys Ther, 2011, 91: 879-893. [Medline] [CrossRef]

17) Macedo AM, Oakley SP, Panayi GS, et al.: Functional and work outcomes improve in patients with rheumatoid arthritis who receive targeted, comprehensive occupational therapy. Arthritis Rheum, 2009, 61: 1522-1530. [Medline] [CrossRef]

18) Adams J, Burridge J, Mullee M, et al.: The clinical effectiveness of static resting splints in early rheumatoid arthritis: a randomized controlled trial. Rheumatology (Oxford), 2008, 47: 1548-1553. [Medline] [CrossRef]

19) Hammond A, Bryan J, Hardy A: Effects of a modular behavioural arthritis education programme: a pragmatic parallelgroup randomized controlled trial. Rheumatology (Oxford), 2008, 47: 1712-1718. [Medline] [CrossRef]

20) Veehof MM, Taal E, Heijnsdijk-Rouwenhorst LM, et al.: Efficacy of wrist working splints in patients with rheumatoid arthritis: a randomized controlled study. Arthritis Rheum, 2008, 59: 1698-1704. [Medline] [CrossRef]

21) Li LC, Davis AM, Lineker SC, et al.: Effectiveness of the primary therapist model for rheumatoid arthritis rehabilitation: a randomized controlled trial. Arthritis Rheum, 2006, 55: 42-52. [Medline] [CrossRef]

22) Ye L, Kalichman L, Spittle A, et al.: Effects of rehabilitative interventions on pain, function and physical impairments in people with hand osteoarthritis: a systematic review. Arthritis Res Ther, 2011, 13: R28. [Medline] [CrossRef] 
23) Vliet Vlieland TP, van den Ende CH: Nonpharmacological treatment of rheumatoid arthritis. Curr Opin Rheumatol, 2011, 23: 259-264. [Medline] [CrossRef]

24) de Almeida PH, Pontes TB, Matheus JP, et al.: [Occupational therapy in rheumatoid arthritis: what rheumatologists need to know?]. Rev Bras Reumatol, 2015, 55: 272-280. [Medline] [CrossRef]

25) O'Brien R, Woodbridge S, Hammond A, et al.: The development and evaluation of a vocational rehabilitation training programme for rheumatology occupational therapists. Musculoskelet Care, 2013, 11: 99-105. [Medline] [CrossRef]

26) Nasir SH, Troynikov O, Massy-Westropp N: Therapy gloves for patients with rheumatoid arthritis: a review. Ther Adv Musculoskelet Dis, 2014, 6: 226-237. [Medline] [CrossRef]

27) Vital EM, Emery P: Advances in the treatment of early rheumatoid arthritis. Am Fam Physician, 2005, 72: 1002-1004, 1004. [Medline]

28) Pasqui F, Mastrodonato L, Ceccarelli F, et al.: [Occupational therapy in rheumatoid arthritis: short term prospective study in patients treated with anti-TNF-alpha drugs]. Reumatismo, 2006, 58: 191-198. [Medline] 